一報文一

\title{
カーペットの圧縮かたさ感覚に関する基礎的研究
}

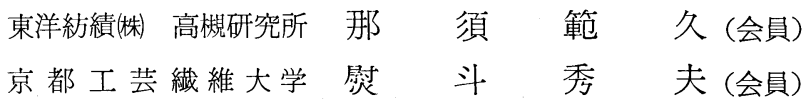

\section{Fundamental Study on the Sensory Compressive Rigidity of Carpets}

\author{
Norihisa Nasu* and Hideo Noshi** \\ * Takatsuki Research Center, Toyobo Co. Ltd., Takatsuki, Osaka \\ ** Department of Textile Technology, Kyoto University \\ of Industrial Arts and Textile Fibers, Kyoto
}

\begin{abstract}
To obtain the fundamental knowledge on the sensory compressive rigidity of carpets, the authors have psychophysically investigated the relation between the sensory compressive rigidity and the instrumental compressive stress.

When the amount of deformation is constant, the relation between the instrumental compressive stress $(S)$ and the sensory compressive rigidity $(R)$ is expressed by the following equation which is different from the Weber-Fechner's law :

$$
\log R=a S+b
$$

where $a$ and $b$ are constants.

Besides the psycho-physical method to estimate the degree of sensory rigidity by a single physical stimulus, the authors have suggested a new method to do so by changing the two stimuli, i.e., stress and deformation. The utility of the new method has experimentally been proved.
\end{abstract}

(Received February 4, 1971)

揰要

目的 カーペットの王縮かたさ感覚と, 物性とつ関䋆を解明にするた奻つ基楚として, 精神物理学的な考え方と手法によって次 の問題を研究する.

（1）手と足について，压縮に対する弾性抵抗力扔よび圧縮変形量のそれぞれと，圧縮かたさ感覚との関係を明らかにすること．

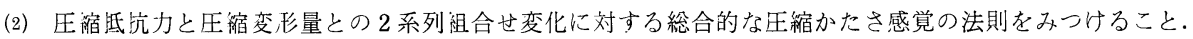

成 果 (1) 圧縮かたさ感覚は, 変形量を一定にして, 压縮抵抗力を变化させた場合, 本実験の範囲では次式で示される.

$\log R=a S+b$

ここに $R$ は感覚, $S$ は刺激, $a, b$ は定数.

しかし抵抗力を一定にして, 圧縮变形量を变化させた場合, この関係は成立しない.

これらは Weber-Fechner の法則と異なる.

（2）精神物理学は主として単一な物理量 (刺激) と, それによって生じる感覚との量的関係を求めるものであるが, 本研究では, 2 種の刺激に対する総合的な感覚の量を，各要素の刺激〜感覚の関係を用いて推定する方法に関する仮説を提出し，本実験の範囲内 ではその仮説がほぼ正しいことを実証した。

（昭和46年 2 月 4 日 受理） 


\section{1. 緒言}

繊維製品に対して人間の感覚を利用して評価する研究 は多数行なわれている. しかし，いずれの研究む官能用 語, または感覚を量として表現した結果について検討し たものであり, 感覚そのものについてはほとんどふれて いない.

カーペットの踏み心地とか, 布の風合いは人間の感覚 を無視しては成り立たないあのであるから，てれを根本 から理解し, 解明するためには感覚そのむのの研究が必 要である.

人間の感覚の研究には各種の方法があり, 取り上げ方 によっては, 全く工学や繊維と関係のない研究になる が，ここではカーペットの圧縮かたさ感覚と，物性との 関係を分析することを目的として, 刺激と感覚との関係 を精神物理的な考え方と手法で检討した。

圧縮かたさ感覚を生じさせる基本刺激は，圧縮抵抗力 之変形量であり, その他, 対象物の表面形態などが多少 関係することが知られている. カーペットの圧縮抵抗力 を力学的に分析すれば, 弾性抵抗力, 粘性抵抗力, 繊維 間の摩擦抵抗力などがあるが，本研究では主要な抵抗力 である弾性抵抗力のみを取り上げた。

変形量はカーペットの場合，厚さによって制限される ことが特長である。またカーペットの場合，足による圧 縮かたさ感覚が重要である。したがって本研究では、ほ ぼ実用可能な範用のカーペットの圧縮初期抵抗力を再現 でき，かつ圧縮量を任意に制限できるスプリングを用い たモデル試験機により, 手と足の圧縮かたさ感覚を女子 パネルを用いて実験し, その法則を求めた. この結果を 利用すれば，カーペットの圧縮かたさ感覚について, 種 々の基本事項が推定できる.

\section{2. 試験機，実験方法ならびにパネル}

\section{1 試験機}

\section{a ）手の指の場合}

第 1 図に示すように簡単なもので，指で押えたときス プリングが圧縮変形され，手の指に圧縮抵抗力が加わる ようにしてある.

このような実験では機械の精度が必要であるので, 圧

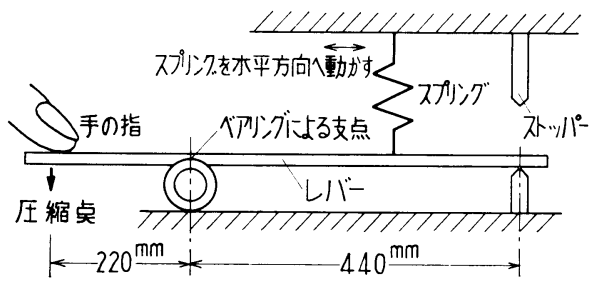

（第 1 図）手の指のかたさ試験機（模式図）
縮点でレバーが左右に振れないように支点のベアリング はニードル ベアリングを用いた．手に加わる力の調整 はスプリングをレバー上で左右に位置を変えることで行 ない，大きく変更するときにはスプリングを取りかえる ようにした，指での位置における変形量の大きさは, レ バー先端のストッパーで調整し， $0.1 \mathrm{~mm}$ まで変化でき るようにしてある. それぞれの変化可能範囲は圧縮力 で $0.02 \mathrm{~kg} \sim 4 \mathrm{~kg}$, 変形量で $0.5 \mathrm{~mm} \sim 200 \mathrm{~mm}$ の間であ る. 指がのる部分の面積は $10 \mathrm{~mm} \times 20 \mathrm{~mm}$ の大きさでセ ルロイド板を敷いてある.とのようなレバーを 8 本並べ て1台の試験機とした.

b ）足の場合

足の場合は試験機にかかる最大の荷重は, 人間の体重 分 (平均 $60 \mathrm{~kg}$ ) であるため 1 台ずつとし強固なもの之 した，そ机を第 2 図に示す，足にかかる荷重や変形量の

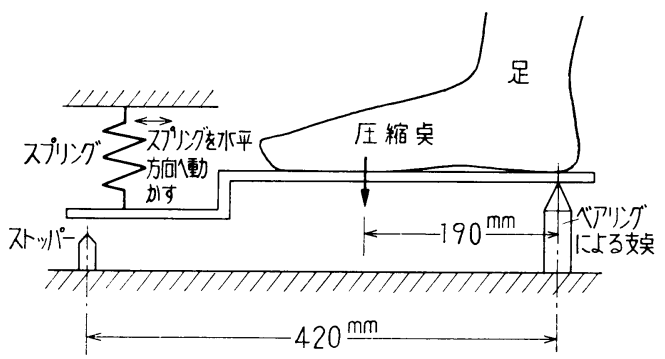

（第 2 図）足のかたさ試験機（模式図）

大きさの決定は，手の指の場合上同様の方法で行なえる ようにしてある.ただし，足の場合はベアリング部のと ころを支点とし，足による踏み込みの力をはかるように

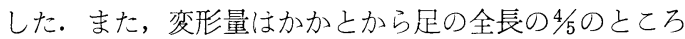
（支点 0 より $19 \mathrm{~cm}$ ）で規定した，変化できる範囲纺荷 重では $0.5 \mathrm{~kg} \sim 60 \mathrm{~kg}$, 変形量では $0.5 \mathrm{~mm} \sim 15 \mathrm{~mm}$ であ 万.

\section{2 実験方法}

ここで求めた人間の手の指と足に関するかたさ感覚の 大きさならびに変形の大きさの感覚は, 次のような条件 で計測したものである。

a）変形量を一定にしておき，荷重を変化させたとき のかたさ感覚

たとえば手の場合では，変形量を $4 \mathrm{~mm}$ に設定し， $4 \mathrm{~mm}$ 変形したとき荷重の大きさが $120 \mathrm{~g}, 200 \mathrm{~g}, 350 \mathrm{~g}$, $700 \mathrm{~g} ， 1000 \mathrm{~g}$ になるように変化させ， $200 \mathrm{~g}$ の刺激を 1 組の内の標準刺激としてそれぞれの荷重レベルのものを 組み合わせて 1 組の刺激とした. このような荷重レベル の変化を $2.5 \mathrm{~mm}, 6 \mathrm{~mm}, 8.5 \mathrm{~mm}, 12 \mathrm{~mm}$ の変形量に ついてかたさ感覚民度を求めるのがこの実験である.

足の場合は変形量のレベルは手の場合と同じである が，荷重は各変形量で $4 \mathrm{~kg} ， 6 \mathrm{~kg}, 9 \mathrm{~kg}, 13 \mathrm{~kg}, 18 \mathrm{~kg}$ 
となるようにした。

b ）荷重を一定にしておき, 変形量を変化させたとき のかたさ感覚

これす例を手の場合にとると，レバーを押えたときの 荷重が $200 \mathrm{~g}$ になるようにし，乙の荷重に達するときの 変形量が $2.5 \mathrm{~mm}, 4 \mathrm{~mm}, 6 \mathrm{~mm}, 8.5 \mathrm{~mm}, 12 \mathrm{~mm}$ 之 変化させて, 変形量 $4 \mathrm{~mm}$ の之きのかたさを基準にし て, それぞれの刺激についてかたさ感覚を求めるもので ある。

c）荷重を一定にしておき变形量を変化させたときの 変形量の感覚

手の場合, 足の場合, いずれもそれぞれ規定の荷重に 達するまでの変形の大きさが $2.5 \mathrm{~mm}, 4 \mathrm{~mm}, 6 \mathrm{~mm}$,

$8.5 \mathrm{~mm}, 12 \mathrm{~mm}$ になるように変化させ， $4 \mathrm{~mm}$ の変形 量を標準刺激としてそれぞれの変形量変化について変形 の大きさの感覚を求めるあのである. 変形量の規定は試 験機のところで述べたと抢りである.

以上の 3 種である.こ机らはいずれも感覚尺度といわ れるあのであり，スプリングの強さが(a)や(b)にしたがっ て変化したときは, 人間のかたさ感覚, (c) 流変形感覚が どのように変化するかをみるあのである.

感覚尺度を求妨方法は種々ある ${ }^{1}$. 我々がここで用 いた方法は洹常和法である。ある刺激の標準刺激に対す る比率や大きさを求める方法はいろい万あるが，たとえ ば倍数法というようなAに対するBの倍率（ここではか たさ感覚) を求める場合, 我々の予備実験ではパネルか ら答えにくい上いう苦情がでてきたので, 答えやすい恒 常和法をとった。

簡単にその方法を述べる，パネルに刺激 $\mathrm{A}$ と刺激 $\mathrm{B}$ 比較させ，A と Bによるそれぞれの感覚の点数をつけさ せる. そのとき 2 つの感覚の大きさを加えて 100 亿した とき $\mathrm{A}$ は何点, $\mathrm{B}$ は何点というように表現してもらう. たとえば Aには25点，Bに75点をつけたとすると，Bの A 亿対する感覚の大きは 3.0 であり, 逆に $\mathrm{A} の \mathrm{~B}$ 亿対す

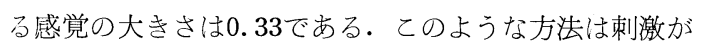
3つあってあ同様に用いることができる.ここでは提示 する刺激の值は必ず 2 つで 1 組とした.

パネルには『2つの刺徼を手または足で押えて, 合計 のかたさ感覚が 100 になるように, それぞれに点数をつ けて下さい。』また, 変形量については『圧縮したとき 変形する大きさの感覚を 2 つの刺激で合計 100 亿なるよ うに点数をつけて下さい』と言い, 刺激の提示を行なっ た。

提示する回数は, 被験者が同一の組に対しては何度む 実験を繰り返すととを許した. この点から刺激の提示に 対する順序効果はない. 実験にはカーペットを踏むよう な状態で実施した。刺激提示間隔は特に定めなかった。
上記のような実験を重ねて感覚の比率を求めると，0 点から適当な距離にそれぞれの刺激に対応する感覚の大 きさを位置づけることができる，そして，その中のどれ か 1 つの刺激の感覚の大きさに単位の值をむたせる之, その他の刺激は容易に尺度化することができる，パネル は某女子大学家政学部被服科学生 30 名である.

\section{3. 実験結果}

3.1 手の指の場合

圧縮かたさ感覚については,

（1）压縮抵抗力を一定にしておいて，圧縮変形量を变 化させた場合

（2）压縮変形量を一定にしておいて，抵抗力を変化し た場合

の 2 上おりが考えられる．とのようないずれの場合につ いて屯, 圧縮抵抗力は $1 \mathrm{~cm}^{2}$ (手の人さし指の圧縮点の 面積）当たりで， $120 \mathrm{~g} ， 200 \mathrm{~g}, 350 \mathrm{~g}, 700 \mathrm{~g}, 1000 \mathrm{~g}$ の 5 水準であり, 圧縮変形量は $2.5 \mathrm{~mm}, 4 \mathrm{~mm}, 6 \mathrm{~mm}$ $8.5 \mathrm{~mm}, 12 \mathrm{~mm}$ の 5 水準である. 第 3 図, 第 4 図汪手 の指のかたさ感覚尺度の大きさを示す.

第 3 図は $2.5 \mathrm{~mm}$ 変形させたとき $120 \mathrm{~g}$ の力がかかる むの，2.5mm 変形させたとき $350 \mathrm{~g}$ の力がかかるもの $\cdots$ …というように, 変形する量を一定にしておいて規定変 形量変形したときに，120g，200g，…1000g の力がか かるように試験機のレバーを調節し， $200 \mathrm{~g}$ の感覚の大 きさを 1 としたときの各水準の 感覚の大きさを示した むので, 変形量の大きさを $2.5 \mathrm{~mm}, 6 \mathrm{~mm}, 8.5 \mathrm{~mm}$ と

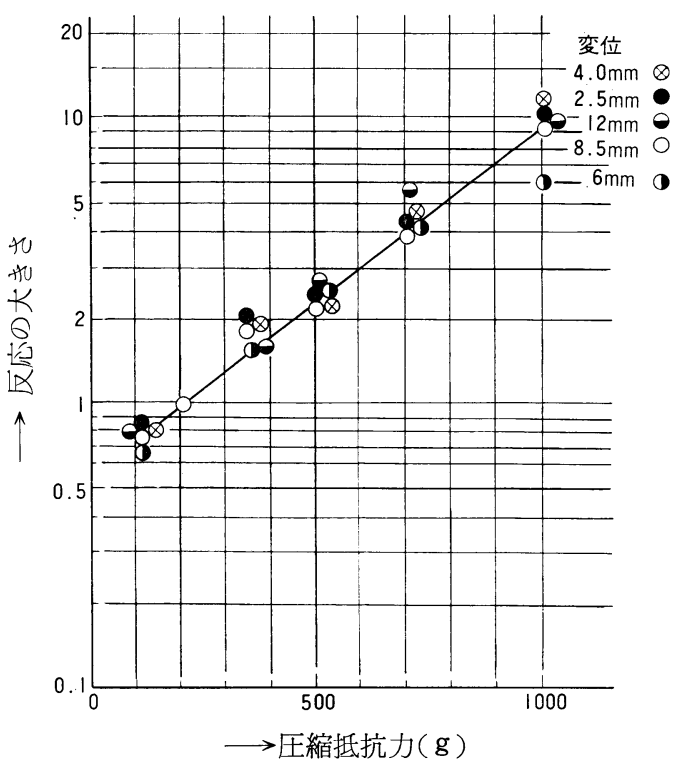

（第 3 図）かたさの感覚尺度（手の指） 圧縮変形量を規定, 圧縮抵抗力 $200 \mathrm{~g}$ の感覚を 1 とする。 


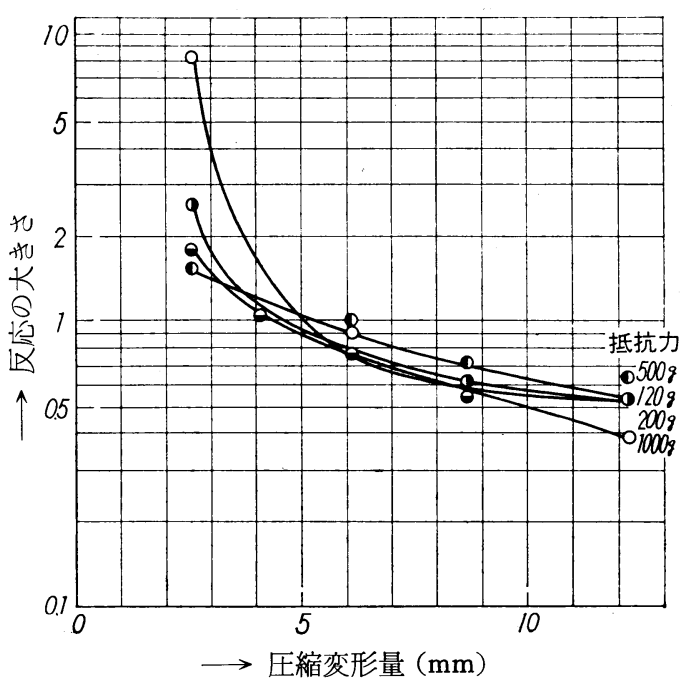

（第 4 図）かたさの感覚尺度（手の指）

圧縮抵抗力を規定, 変形量 $4 \mathrm{~mm}$ の感覚を 1 上 する。

規定したときのグラフである. 第 4 図は逆にある変形量 まで変形させると，一定の力が手の指に加わるようにし たむので，指に加わる力その屯のは常に一定にした場 合である.

第 5 図には念のため手における変形量の感覚の大きさ の結果を示す.

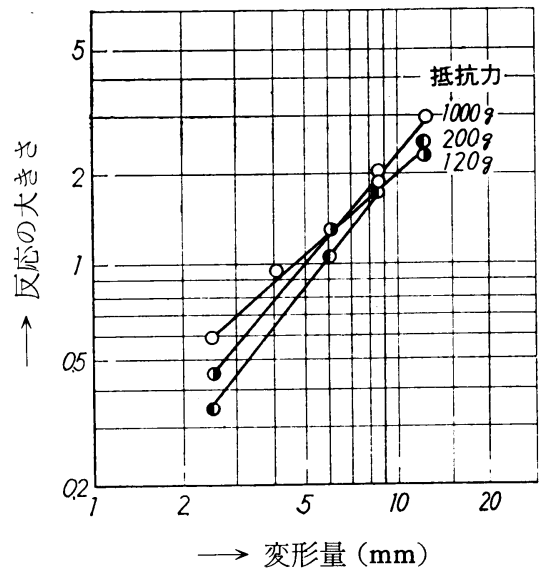

(第 5 困) 変位の感覚尺度 (手の指) 変形量 $4 \mathrm{~mm}$ の感覚を 1 とする.

これらの図から人間のかたさ感覚の大きさは, 常に物 理量之比例的な直線関係で増減するのではないととがわ かる.

3.2 足の場合

足についても同様の実験を行なった，足の場合は荷重 は $4 \mathrm{~kg}, 6 \mathrm{~kg}, 9 \mathrm{~kg}, 13 \mathrm{~kg}, 18 \mathrm{~kg}$ の 5 水準であり,
変形量は手の場合之同様に $2.5 \mathrm{~mm}, 4 \mathrm{~mm}, 6 \mathrm{~mm}$, $8.5 \mathrm{~mm}, 12 \mathrm{~mm}$ の 5 水準である. それらの結果を第 6 図 ～第 8 図に示す.

\section{4. 考 察 \\ 4.1 考察 1}

実験結果から人間のかたさ感覚, ならびに变形量に対 する感覚について考察してみよう.

第 3 図，第 6 図にみるように压縮変形量を規定した場 合, 手の指む, 足屯, 刺激の増加とと屯に感覚の対数は 直線的に増大する.つまり

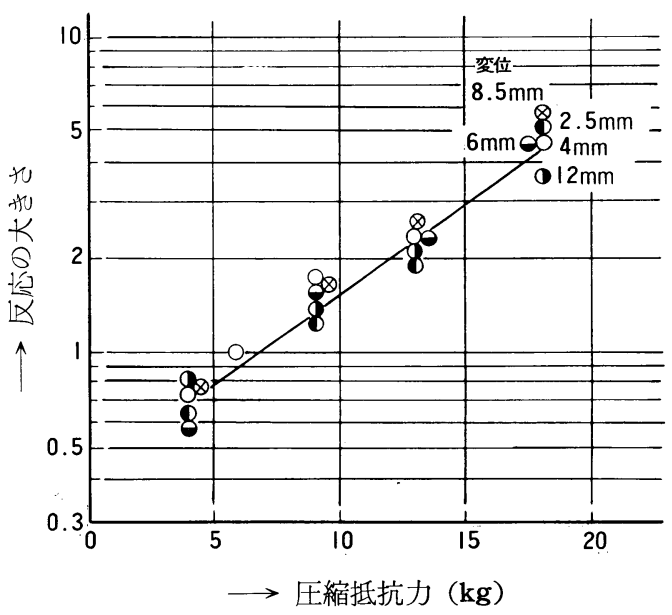

（第 6 図）かたさの感覚尺度（足） 圧縮変形量を規定, 圧縮抵抗力 $6 \mathrm{~kg}$ の感覚を 1 とする.

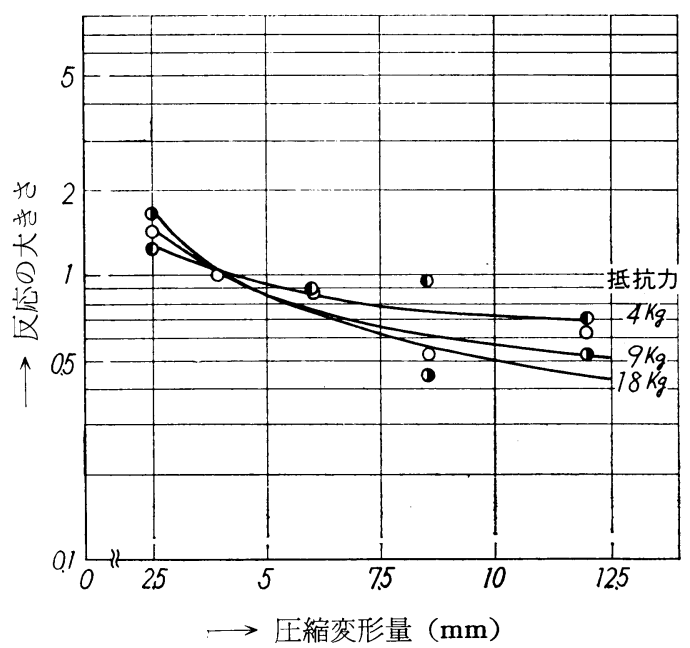

（第 7 図）かたさの感覚尺度（足） 圧縮抵抗力を規定, 変形量 $4 \mathrm{~mm}$ の感覚を 1 と する。 


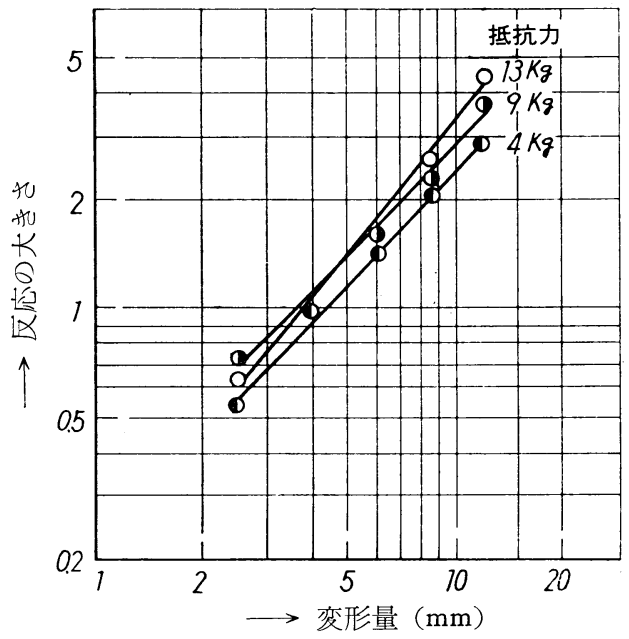

（第 8 図）変位の感覚尺度（足）

変形量 $4 \mathrm{~mm}$ の感覚を 1 とする.

$$
\log R=a S+b
$$

$R$; ある基準に対するかたさ感覚の大きさ（倍数）

$S$; 西る基準刺激住対する刺激の倍数

$a, b ;$ 定数となる.

乙れは精神物理学的法則としてょく知られている Weber-Fechner の法則と異なっている. WeberFechner の法則は特定範囲の刺激について適用されるも のであるから，ての法則からはずれることは珍しいとと ではないが，本研究の結果は実用上は重要である。すな わち, Weber-Fechner の法則では感覚の增加割合は刺 激の增加割合より少ないが，本研究結果では前者のほう が大きくなる，なお，規定する変形量の大きさを変化さ せても，ほほ平行線上にあることは，我々人間は相当紧 密に压縮抵抗力を受けとめる能力があるととを示すあの 之考えられる. 一方圧縮抵抗力を規定して, 変形量を変 えてかたさを比較したときには第 4 図, 第 7 図に示した ように，感覚の対数之刺激之は直線状にはならない。ま た, 手の場合のほうが圧縮変形量の増加によるかたさ感 覚の低下の程度が，足の場合のそれよりも大きい。乙れ は手のほうが足に比べて眼に近いため，視覚による影響 が入っているあのと考えられる，変位に対する感覚は， 第 5 図, 第 8 図に示したように手の指の場合む足の場合 屯, 感覚 $R$ の対数之刺徼 $S$ (変形) の対数とがほぼ直 線関係を示している. すなわち， $R=a S^{n}$ の関係で示さ れる. ここで $a, n$ は定数である.つまり变形の感覚之 かたさの感覚とでは法則がやや異なっている，なお変形 の感覚として手と足の相違は, 足の場合, 手より屯やや 大きく変形するように感じとっている.

次に，とてで計測したかたさ感覚の大きさのばらつき について検討する．第 3 図の手の指のかたさ感覚を求め
た結果のうち変形量の大きさが $2.5 \mathrm{~mm}$ における各水準 の荷重の反応の大きさの標準偏差を調べると， $120 \mathrm{~g}$ と $200 \mathrm{~g}$ の比較では 0.13 倍, $200 \mathrm{~g}$ と $350 \mathrm{~g}$ の比較では 0.72 倍, $200 \mathrm{~g}$ と $500 \mathrm{~g}$ では 0.82 倍, $200 \mathrm{~g}$ と $700 \mathrm{~g}$ では 1.23 倍， $200 \mathrm{y}$ と $1000 \mathrm{~g}$ では 3.5 倍であった. この倍数は小 さいほうの荷重のかたさ感覚の大きさを 1.00 として求め た大きいほうの荷重の感覚の大きさの標準偏差である. $200 \mathrm{~g}$ は標準刺激（この感覚を 1.00 とした）であるため 標準偏差は求められない，とのような結果を用いて，パ ネル数 30 名で平均值の差の検定から, 感覚の大きさが平 均值で何倍以上あればパネルが答えた答值が有意である かを検討した。 その結果， $120 \mathrm{~g}$ と $200 \mathrm{~g}$ の比較では 0.09 倍, $200 \mathrm{~g}$ と $1000 \mathrm{~g}$ の比較では2.46倍である. てれらの值 之第 3 図の值を比較すると, 求めた值は有意であること がわかる．また第 4 図の压縮抵抗力を一定にしたときの かたさ感覚の場合の標準编差の大きさは，压縮抵抗力を 変化させたときのかたさ感覚の標準偏差の值の約 $1 / 3$ であ ったので第 4 図の結果む有意であった。さらに压縮変形 量感覚においても同様の結果であった。

足の場合も手の指の場合之同様にして求める之, 圧縮 抵抗力変化のときの標準偏差の大きさは， $4 \mathrm{~kg} \sim 6 \mathrm{~kg}$ の比較では 0.15倍, $6 \mathrm{~kg} \sim 9 \mathrm{~kg}$ のときは 0.6倍, $6 \mathrm{~kg}$ 〜13kg では0.8倍, $6 \mathrm{~kg} \sim 18 \mathrm{~kg}$ のときは1.5倍であった (この倍数む小さいほうの荷重のかたさ感覚の大きさを 1.00 として求めた大きいほうの荷重の感覚の大きさの標 準偏差である)。乙れらの值を用いて手の指の場合之同 様に，平均值つ差の検定をした結果，すべて有意となっ た。

以上のことから我々が求めたかたさ感覚に関する法則 の妥当性は確かめられた。 なお，乙れらの結果は個人間 のばらつきに関するむのである. 今回のテストでは同一 刺激の組の綝返しテストは行なっていないので, 個人内 の変動は求めていない.

\section{2 考察 2}

さて単一の物理量に対する人間の感覚の変化する様子 は，以上検討してきたとおりである.

我々が日常取り扱っている刺激を考えてみると，た之 えば騒音は周波数之振幅の組み合わされたものであり， 色彩の場合もある色相がきまる之明度, 彩度の組合せで 表現できる. またスプリングの圧縮かたさ感覚も, 圧縮 抵抗力と圧縮変形量の組合せできまる刺激に対する感覚 で表現されるものである. このように単一の物理量を数 個組み合わせて 1 つの刺激として我々は受けとめている のであって，必ずしあある刺激を受容したときにそれを 分析的に感知しているのではないととが筆者らの経験か ら推定できる. ここで単一の感覚として得られた結果 を，このような総合された感覚として表現する方法を試 
みた。

感覚を取り扱う場合, 圧縮に要する時間の効果が問題 になるが，一応我々人間の歩行中のことを考えると， 1 $\min$ 間に $60 \mathrm{~m}$ 歩くとすると体重によるスプリングへの 踏み込みの時間は, 3/60～5/60sec であって ${ }^{2)}$, 残りの 大部分は身体の水平方向の移動と, 身体をさらに 1 歩進 めるためのキックの時間であるため, 3/60sec と5/60sec というような差は，乙こでは無視することにする.

総合感覚の仮説は, 感覚の伝達機構をブラックボック スにおきかえて, これに電気工学の四端子綱理論 ${ }^{3 !}$ を応 用するモデル的な考え方である.ここに，

$M_{1}:$ 圧縮抵抗力変化の之きの処理機構

$M_{2}:$ 圧縮変形量変化のときの処理機構

とすると，モデルは第 9 図に示すような図になる.

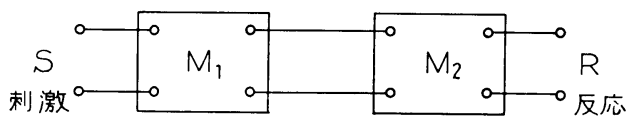

（第 9 図）かたさ感覚処理機構のブラックボックス

ここで $\left(M_{1}\right),\left(M_{2}\right)$ のマトリックスは，たとえば手 の指の場合, 第 3 図, 第 4 図の結果を行方向に荷重レベ ル, 列方向に変位レベルをとり, $[R i j] を M_{1}$ の処理 機構によるマトリックス, $\left[R j k 〕\right.$ を $M_{2}$ の処理機構に よるマトリックスとすると，

$$
R^{\prime}=[R i j][R j k]
$$

で示されるが, ここで $R^{\prime}$ のマトリックスの要素を標準 化するため, 行の数（ここでは 5 ）で割り, 整理しなお したマトリックスの形にするとよい. 計算した結果が次 のマトリックスである.

\begin{tabular}{r|c|cccccc} 
& $2.5 \mathrm{~mm}$ & $4.0 \mathrm{~mm}$ & $6.0 \mathrm{~mm}$ & $8.5 \mathrm{~mm}$ & $12.0 \mathrm{~mm}$ \\
$120 \mathrm{~g}$ & 2.60 & 0.82 & 0.62 & 0.50 & 0.44 \\
$200 \mathrm{~g}$ & 3.10 & 1.00 & 0.88 & 0.62 & 0.53 \\
\hline $350 \mathrm{~g}$ & 5.33 & 1.79 & 1.57 & 1.10 & 0.95 \\
$500 \mathrm{~g}$ & 7.36 & 2.21 & 1.94 & 1.34 & 1.18 \\
$700 \mathrm{~g}$ & 15.07 & 4.57 & 4.05 & 2.80 & 2.43 \\
$1000 \mathrm{~g}$ & 27.13 & 8.54 & 7.50 & 5.23 & 4.40
\end{tabular}

このマトリックスは手の指の場合であるが，足の場合 は次のようになる.

$$
R(\text { 足 })=\begin{array}{r|llllll|}
\hline & & 2.5 \mathrm{~mm} & 4.0 \mathrm{~mm} & 6.0 \mathrm{~mm} & 8.5 \mathrm{~mm} & 12.0 \mathrm{~mm} \\
\hline \mathrm{kg} & 1.02 & 0.72 & 0.62 & 0.46 & 0.46 \\
\hline \mathrm{kg} & 1.40 & 1.00 & 0.85 & 0.65 & 0.63 \\
9 \mathrm{~kg} & 2.26 & 1.59 & 1.36 & 0.99 & 0.99 \\
13 \mathrm{~kg} & 3.16 & 2.24 & 1.91 & 1.43 & 1.38 \\
18 \mathrm{~kg} & 6.43 & 4.64 & 3.97 & 3.11 & 2.88
\end{array}
$$

これらのマトリックスは物理的には，圧縮抵抗力のか たさ感覚を压縮変形量のかたさ感覚で重みづけを行な
い, 平均化したものである. また，乙れらのマトリック スは手の指の場合は圧縮抵抗力が $200 \mathrm{~g}$, 圧縮変形量 4 $\mathrm{mm}$ のかたさ感覚を 1.0, 足の場合は圧縮抵抗力が $6 \mathrm{~kg}$ 圧縮変形量 $4 \mathrm{~mm}$ のかたさ感覚を 1.0 として, 手の指掠 よび足のかたさの感覚の大きさを標準化した，てのよう なモデル的な考えによるかたさ感覚についての総合的な 表示の妥当性を，実験結果との比較によって検討する。

ここで刺激の大きさの表示を次のようにする，たとえ ば，圧縮抵抗力が $500 \mathrm{~g}$ でそのときの变形量が $6 \mathrm{~mm}$ の とき $500 \mathrm{~g} / 6 \mathrm{~mm}$ とする.

実験は圧縮抵抗力と压縮変形量をそれぞれ変えて, 異 なる刺激の大きさを手の指の場合 7 組，それぞれについ て 1 対比較を用い, 恒常和法により答えてもらった（第 1 表参照).

たとえば 1 の刺激は $500 \mathrm{~g} / 6 \mathrm{~mm}$ で第(1)式のマトリッ クスの要素は 1.94 である. 3 の刺激は $350 \mathrm{~g} / 12 \mathrm{~mm} て ゙$ 0.95であるため 1 の 3 亿対するかたさ感覚の大きさは， 理論的には $1.94 / 0.95=2.04$ となる. それが実験では 2.62となり，ほぼ一致した結果が得られている．てのよ うにして刺激 1 から 7 までの組合せについて実験した 結果を第 1 表に示す。第 2 表には足について 行なった

（第 1 表）かたさ感覚（手の指）

表中の值は，（ $i$ ）のかたさ感覚は $(j)$ のかた

\begin{tabular}{|c|c|c|c|c|c|c|}
\hline $\begin{array}{l}j \\
\end{array}$ & 2 & 3 & 4 & 5 & 6 & 7 \\
\hline 1 & $\begin{array}{l}0.75 \\
0.43 \\
\end{array}$ & $\begin{array}{l}2.62 \\
2.04\end{array}$ & $\begin{array}{l}0.90 \\
0.70\end{array}$ & $\begin{array}{l}2.29 \\
3.13 \\
\end{array}$ & $\begin{array}{l}1.22^{*} \\
0.37\end{array}$ & $\begin{array}{l}1.78 \\
1.94\end{array}$ \\
\hline 2 & & $\begin{array}{l}4.40 \\
4.81\end{array}$ & $\begin{array}{l}1.53 \\
1.63\end{array}$ & $\begin{array}{l}5.69 \\
7.37 \\
\end{array}$ & $\begin{array}{l}2.35^{*} \\
0.86\end{array}$ & $\begin{array}{l}2.93 \\
4.57 \\
\end{array}$ \\
\hline 3 & & & $\begin{array}{l}0.41 \\
0.34\end{array}$ & $\begin{array}{l}0.79 \\
1.51\end{array}$ & $\begin{array}{l}0.61^{*} \\
0.18\end{array}$ & $\begin{array}{l}0.91 \\
0.95\end{array}$ \\
\hline 4 & & & & $\begin{array}{l}2.53 \\
4.51\end{array}$ & $\begin{array}{l}1.72 \\
0.53 \\
\end{array}$ & $\begin{array}{l}2.75 \\
2.80 \\
\end{array}$ \\
\hline 5 & & & & & $\begin{array}{l}0.52^{*} \\
0.12\end{array}$ & $\begin{array}{l}0.91 \\
0.62\end{array}$ \\
\hline 6 & & & & & & $\begin{array}{l}1.25^{*} \\
5.33\end{array}$ \\
\hline
\end{tabular}
さ感覚の $a_{i j}$ 倍であることを示す.なお上段の 值は実験值, 下段の值は(1)式のマトリックス要 素から求めた值である.

$\begin{array}{ccccc}\begin{array}{c}\text { 刺激の } \\ \text { No. }\end{array} & \begin{array}{c}\text { 抵抗力 } \\ \mathrm{g}\end{array} & \begin{array}{c}\text { 変形量 } \\ \mathrm{mm}\end{array} & \begin{array}{c}\text { ばね定数 } \\ \mathrm{g} / \mathrm{mm}\end{array} & \begin{array}{c}\text { マトリッ要素 } \\ \text { ク }\end{array} \\ 1 & 500 & 6.0 & 84.5 & 1.94 \\ 2 & 700 & 4.0 & 175 & 4.57 \\ 3 & 350 & 12.0 & 29.1 & 0.95 \\ 4 & 700 & 8.5 & 82.3 & 2.80 \\ 5 & 200 & 8.5 & 23.5 & 0.62 \\ 6 & 350 & 2.5 & 140 & 5.33 \\ 7 & 200 & 4.0 & 50 & 1.00 \\ r=0.81 & & & \end{array}$


（第 2 表）かたさ感覚（足）

表中の值は，（ $i$ ）のかたさ感覚は（ $j$ )のかた さ感覚の $a_{i j}$ 倍であるととを示す. なお上段の 值は実験值, 下段の值は(2)式のマトリックス要 素から求めた値である.

\begin{tabular}{c|c|c|c|c}
\hline & 2 & 3 & 4 & 5 \\
\hline \multirow{2}{*}{1} & 6.05 & 1.56 & 3.06 & 2.05 \\
& 6.28 & 1.51 & 2.88 & 1.28 \\
\hline \multirow{2}{*}{3} & & 0.35 & 0.67 & $0.75^{*}$ \\
\cline { 1 - 1 } 3 & & 0.25 & 0.47 & 0.21 \\
\hline \multirow{2}{*}{4} & & & 1.93 & 1.41 \\
& & & 1.91 & 0.85 \\
\hline
\end{tabular}

$\begin{array}{ccccc}\begin{array}{c}\text { 刺激の } \\ \text { No. }\end{array} & \begin{array}{c}\text { 抵抗力 } \\ \mathrm{kg}\end{array} & \begin{array}{c}\text { 変形量 } \\ \mathrm{mm}\end{array} & \begin{array}{c}\text { ばね定数 } \\ \mathrm{kg} / \mathrm{mm}\end{array} & \begin{array}{c}\text { マトリッ要素 } \\ \text { ク }\end{array} \\ 1 & 18 & 12.0 & 1.50 & 2.88 \\ 2 & 4 & 8.5 & 0.47 & 0.46 \\ 3 & 13 & 6.0 & 2.16 & 1.91 \\ 4 & 6 & 4.0 & 1.50 & 1.00 \\ 5 & 9 & 2.5 & 3.59 & 2.26 \\ r=0.98 & & & & \end{array}$

結果を示す・これら実験值と理論値の一致の程度をみる ために，試みに笑験值と理論值の相関係数を求めると， 手の指の場合は 0.81 , 足の場合は 0.98 と非常に高い值を 得た。こ机らの表の中で*印をつけた組合せについては マトリックス要素值から求如た值之実験值之が比較的大 きくくい違っているものである，乙れの原因は次のよう に説明することができる.

第10図に手の指について，ば敉定数を基準にして，加 たさ感覚の大きさを求めたあのを示す，そ机よると我 々人間の感覚の変化には，2つの変曲点をむっているこ とがわかる。

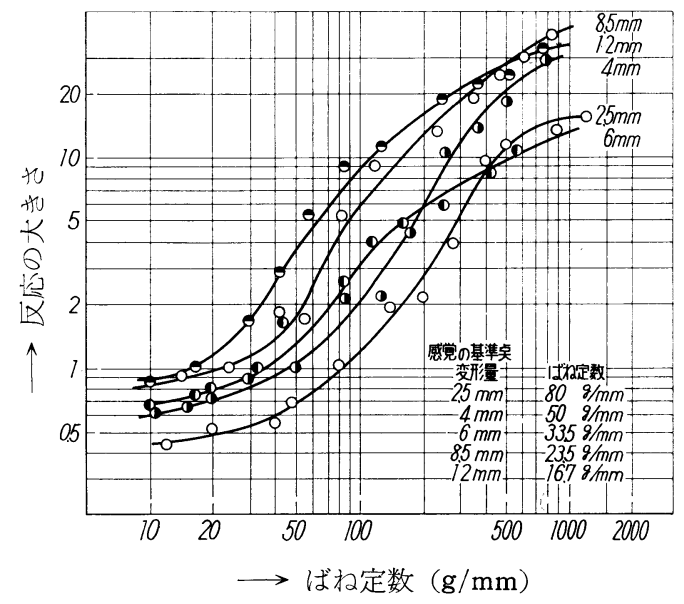

(第10図) かたさ感覚の変化（手の指）

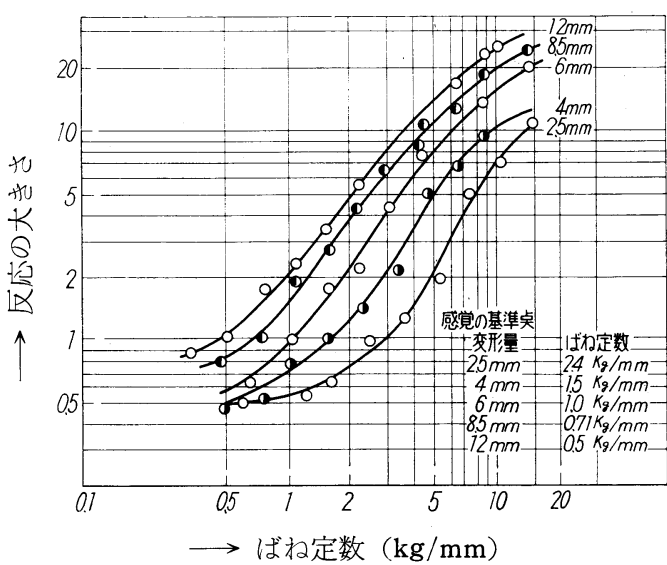

(第11図) 功たさ感覚の変化（足）

足についても同様に，第11図に示すようにS 字状の変 化を示す．このように 1 種の刺激に対する感覚の変化は やや $\mathrm{S}$ 字状曲線をなし, 一般的な眼や耳の感覚の変化の 傾向 ${ }^{4)}$ とよく一致している.

以上の結果から圧縮かたさ感覚は，3つの領域に分割 できるもの上推定される，それらは触覚に近い領域，压 覚の領域, さらに痛覚に近い領域である. このように区 別すると，たとえば，第 1 表における刺激の $3 ， 6$ は第 10 図加ら判断すると, 刺激 3 は触覚に近い刺激であり, 刺激 6 は圧覚の刺激であることから，直接比較される心゙ きむのでないことがわかる．第 1 表，第 2 表の*のつい た組合せでマトリックスから求めた值と実験值とが大き く異なるものの大部分は, 以上のように説明できる. こ のことから，2つの変化する刺激に対する感覚の大きさ は圧縮抵抗力を一定にし，圧縮変形量を変化させたとき の感覚の大きさのマトリックスと, 圧縮変形量を一定に し, 压縮抵抗力を変化させたときの感覚の大きさのマト リックスの積で表現できるという仮定は, 本研究の範囲 内ではほぼ正しいと考えられる.しかし手の指の場合は ばね定数を用いると蝕覚に近い感覚は $40 \mathrm{~g} / \mathrm{mm}$ 以下，压 覚は $40 \mathrm{~g} / \mathrm{mm} \sim 300 \mathrm{~g} / \mathrm{mm}$, 痛覚に近い感覚は $300 \mathrm{~g} / \mathrm{mm}$ 以上であり，足の場合はそれぞれ $1 \mathrm{~kg} / \mathrm{mm}$ 以下， $1 \mathrm{~kg} /$ $\mathrm{mm} \sim 6.5 \mathrm{~kg} / \mathrm{mm}, 6.5 \mathrm{~kg} / \mathrm{mm}$ 以上であり，乙れらの刺 激領域では压縮かたさ感覚をそれぞれ区別して考えるべ きである・したがってマトリックスの要素による比較は 同一種類の感覚領域でのみほぼ許されるすのである。

\section{5. 結 論}

感覚のうち, すでに眼や耳については感覚と物理量の 関係が把握され，実社会で実用に供されている.しかし 風合いに関係する手足のかたさ感覚についてはほとんど 手をつけられていなかった．本研究ではカーペットの圧 縮かたさに対して，感覚面からその基本的な法則をみつ 
けるため, 手と足とについて圧縮かたさ感覚と圧縮抵抗 力, および圧縮変形量との関係を明らかにした. 圧縮変 形量を規定し, 圧縮抵抗力 $(S)$ を変化させたときのかた さ感覚の大きさ（反応 $R$ ) は, $S$ のでく大きい範囲と小 さい範囲を除けばほぼ,

$$
\log R=a S+b
$$

にしたがうことが明らかになった。ただし， $a, b$ は定 数である. この関係は手の指の場合, 足の場合にああて はまる.また刺敫の大きさが, 刺激閾から刺激項まで变 化する広い領域をみると $S \sim R$ の関係が $\mathrm{S}$ 字状曲線をな している.

次に精神物理学的手法は単一物理量を指定し, それ以 外の物理量は厳密に規定し, 指定した物理量に関する感 覚の大きさなどについて実験するあのであるため，2つ の物理量变化に対する感覚は扱うことはできなかった。 そこで本研究では感覚マトリックスの積を利用するて とによって，2つの刺激が同時に变化したときの感覚の
大きさの変化の様子を把握する仮説を提出した. ての仮 説は圧縮かたさ感覚についての本研究の実験範囲内で は, 実験結果とほぼ一致した. その他のかたさ感覚, た とえば粘性抵抗による圧縮かたさ, あるいは曲げかたさ などにもこの仮説が適用されれば，次第に普遍性を持つ ことになる。

本論文はモデル実験による検討結果である．機会をあ らためて実用カーペットについて報告する予定である.

\section{参考文献}

1) Guilford J. P ; 秋重義治訳, 精神湖定法, 培風館 (1967)

2) "The forces applied to the flower by the foot in walking" ; Building Research Board, April, 1960

3) 電気学会編; 電気回路, 電気学会

4) 桑原増太郎編; 情報科学講座 B9-1, 感覚情報 II, 共 立出版 (1969) 